\title{
Diaspora Governance: The Instrumentality of Informal Religio-Politico Structures for Migrant Integration among Ghanaian Diaspora in Guangzhou, China
}

\author{
Patrick Lebene Adonooㄹ, Seth Christopher Yaw Appiah ${ }^{2,3}$ \\ ${ }^{1}$ School of Government, Sun Yat-sen University, Guangzhou, China \\ ${ }^{2}$ Department of Sociology and Social Work, Faculty of Humanities and Social Sciences, Kwame Nkrumah University \\ of Science and Technology, Kumasi, Ghana \\ ${ }^{3}$ Center for International Health, Ludwig-Maximilians University, $\mathrm{CIH}^{\mathrm{LMU}}$ University of Munich, Munich, Germany \\ Email: sychrist2007@gmail.com
}

How to cite this paper: Adonoo, P. L., \& Appiah, S. C. Y. (2019). Diaspora Governance: The Instrumentality of Informal Religio-Politico Structures for Migrant Integration among Ghanaian Diaspora in Guangzhou, China. Advances in Applied Sociology, 9, 357-369.

https://doi.org/10.4236/aasoci.2019.98026

Received: June 14, 2019

Accepted: August 12, 2019

Published: August 15, 2019

Copyright $\odot 2019$ by author(s) and Scientific Research Publishing Inc. This work is licensed under the Creative Commons Attribution International License (CC BY 4.0).

http://creativecommons.org/licenses/by/4.0/

cc) (i) Open Access

\begin{abstract}
Africans presence in Guangzhou epitomizes a sweet bitter fragrance for China relative to governance, law compliance and international relations. This study grounded on a case study design with Ghanaians Living in Guangzhou as case investigated who, how and the where of African Ghanaians in the Chinese diaspora governance structure. The study setting was the Ghanaian Church in the De kanlu area in Guangzhou where most Ghanaian lived in Guangzhou, China. The qualitative case study approach was deemed appropriate method for the study. Through participant and non-participant observation and key informant interviews supported with Focus Group discussions, data were collected through direct visits to the Ghana restaurants, Ghana Community meetings and the Ghanaian church for 11 months between in March 2016 and January 2017. Data were analysed using emerging and constant thematic analysis. Central to the findings was the observation that the Ghanaian diaspora in Guangzhou has two main approaches of governance: the formal and the informal approaches. The focus of the former approach facilitations is engineered by the Guangzhou city government while the informal approach relied on the Church of Pentecost in Guangzhou (Ghana Church) in-built and internalized working and governance structures for governing Ghanaians. The informal self-governance approach was considered more trustworthy, effective and efficient compared to the formal arrangement. This new diasporan preferred governance approach has an eclectic character and defined as the religio-political diaspora governance approach emanating from the Ghanaian community assessment and evaluation.
\end{abstract}


The formal approach (the constitutional draft) was considered as woeful outdated and inadequate governance framework for the Ghanaian diaspora community. There however is a continued ideological influence of Ghanaian diaspora by the Chinese political and governmental systems nurturing a hybridized governance approach and structure which is kept in a continuing redefining nature.

\section{Keywords}

Diaspora, Religio-Politico, Governance, China, Ghana

\section{Introduction}

Whilst presenting a new paradigm and opportunity for different stakeholders, the quest to understand and effectively govern Africans in China has become major concerns both to Chinese and African governments. In 2008, Li \& Du (2012) reported that the China People's Consultative Conference (CPCC) reprimanded the Guangzhou government because they had failed in monitoring and controlling its foreigners, particularly African population effectively. The Chinese government seemingly failed more after tension increased when Africans protested in Guangzhou in 2009 after two African textile retailers were seriously injured escaping a police raid. A similar protest occurred in 2012 after the death of an African in police custody. The Guangzhou city government has therefore increased controls and raids of business locations in the Xiaobeilu and Guangyuanxi areas where Africans in Guangzhou predominantly reside.

In a simultaneous approach, the Chinese national government has tightened entry and residence regulations so that only short-term visas are issued to many foreigners, particularly Africans. Foreigners are unable to obtain extensions for their F visas to conduct business (Bodomo \& Ma, 2010; Müller \& Wehrhahn, 2013; Bork-Hüffer et al., 2014). Coupled with this background, Bodomo \& Ma (2010) reports that the Guangzhou's security officials are characterized with corruption and inefficiency. They claim "more efficient, more professional, less corrupt and more racially tolerant" enforcement personnel found in Yiwu, which accounts for fairer treatment of Africans compared to treatment observed in Guangzhou. These events mimic difficult phenomenon of migration in Europe and other parts of the world generally. Migration with its evolving challenge has come to be established as one of the major difficulties for nation governance today-both the giving and the receiving countries.

The results of the treatment conditions meted out to Ghanaians, in many instances unfavourable particularly among those with permit and diaspora stay condition have triggered calls home to their countries. In 2009, the president of Ghana, his excellency John Agyekum Kuffour gave an unpresidented appeal to Ghanaians in the diaspora to return to Ghana to urgently aid in the development of the country. This call has been reiterated by Ghana's president Nana Addo 
Danquah Akuffo Addo since assuming office and has gone ahead to establish an office for the Ghanaians in the diaspora. These events have huge expectation and hence demand is laid on the Ghanaian diaspora across the globe by the Ghanaian government to return and contribute to their nations development particulaly when some are receiving unfvaourable treatment beyond the shores of Ghana.

At the height of this national expectation for the Ghanaian diaspora, China is becoming the new destination for many Ghanaians and Africans in general. Meanwhile, Guangzhou (the major city that prides itself with the biggest population of African migrants) as earlier emphasized is becoming increasingly unwelcoming in its policies and practices to these sojourners (Bodomo \& Ma, 2010). In an address given by his Excellency Dr Charlse Dwamena (the Ghanaian Deputy Ambassador to China), estimated 11,000 registered Ghanaians visit Guangzhou every year (Bodomo \& Ma, 2010). This number is arguably more than that of any other city in China. Meanwhile, (understandably) the Ghana Embassy is situated in Beijing which is in northern China while Guangzhou is in southern China. Coupled with this is the fact that as at the time of conducting this study, there existed no Ghanaian consulate in Guangzhou to manage the affairs of the increasing growing Ghanaian population and community in Guangzhou.

Under these clear circumstances of diasporan challenges, an obvious question arises; how do Ghanaiansin the diaspora in Guangzhou govern themselves? In effect, what social construct relative to governance arrangement keeps Ghanaians in such an environment? It is, therefore, the preoccupation of this paper to investigate the governance systems that the Ghanaians diaspora have adapted to be able to stay harmonious in China. The paper thesis out the relationship between diaspora and governance; specifically how the Ghanaian diaspora governs itself. It itemizes the various structures and mediums of the Ghanaian social construct, political relay and economic behaviour diaspora.

\section{Methods}

\subsection{Study Setting}

This study was carried out in Guangzhou in the People Republic of China. Guangzhou the capital of Guangdong Province is a city in southern China, located about 120 kilometres north-northwest of Hong Kong and glories as the fourth largest city (after Shanghai, Beijing and Chongqing) with a population of about 12,548,000 million people as at 2018 (Index Mundi). Guangzhou covers an area of 7434.4 square kilometres and it is geographically located in southern China along the Pearl River Delta margin strategically in an area known to the rest of the world as the "factory of the world". Guang also calls Guangzhou the Millennium Commercial City and explains the millennium city by saying that Guangzhou has been in existence for about two thousand years and was the origin of the "Maritime Silk Road" in ancient China. The city's uniqueness is firmly established in history, culture, religion, economy and population amongst its 
co-equals. Guangzhou has also been one of the major destination points for migrants (both local and international) including the newly emerging African migrants.

Current statistics indicate that there are now more Africans in southern Chinese cities especially Guangzhou (than in any other part of China (Li et al., 2007). Hither to this, Guangzhou has had the history of being the first place in China to make contact with African or other dark-skinned slaves from overseas. This was due to the fact that the Port of Canton (its main port) was the only port opened to foreign trade prior to 1840. Even though contested, Africans in Guangzhou are estimated to amount to 500,000. The African community is normally located in two specific areas namely Sanyuanli and Xiaobei. Bodomo (2012) states that many of these Africans are businessmen who deal mainly in clothes, shoes and cheap electronic goods. It is also worth mentioning that there are also a growing number of African students in Guangzhou. These students are normally bachelor and master's degree students who are taking advantage of the relatively cheap tuition fees of the Chinese Universities in Guangzhou. Guangzhou is attractive to Africans for many various reasons. Among the many possible reasons, explaining the huge presence of Ghanaian presence (African at large) Guangzhou are business accessibility, policy regulations, history and climate.

Guangzhou is a well-stocked city for the enhancement of business activities. It's recognized logistical services and transportation structures intertwined with properly located wholesale markets, warehousing infrastructures make it the one stop shop for many domestic and foreign traders (Cai \& Yu, 2008; Xu, 2010). Business and commerce opportunities in Guangzhou are arguably the main reason why many Ghanaians have chosen to settle in Guangzhou. Secondly, until fairly recently, Guangzhou served as a safe haven for foreigners with its municipal government and local control being relatively relaxed compared to other major cities in China. By this, the city gained the nickname "the chocolate city" (CNN News 16, May 2016). Accessibility to accommodation facilities in the private market without much official restriction or local opposition has been a major consideration factor for many of these traders (Xu, 2010). Thirdly, Guangzhou is a historic iconic.

The city has a 2200-year-long history with a long-established administrative status in China. Within these years many major international events have introduced Guangzhou to the rest of the world; giving the city a dent of interest for migrants from around the world with Ghanaians being no exception. Finally, the Climate of Guangzhou is another high enabling factor for many Ghanaians settlers. Guangzhou is one of the tropical cities in China. The annual mean temperature is 30 degrees Celsius which is very typical of the weather condition in Ghana. The average lowest annual temperature is 10 degrees Celsius-considered bearable for many Ghanaians. Cold and snowy weather conditions, which many Africans are not accustomed to, are not found in Guangzhou-making Guangzhou a top- 
most priority for many migrants and settlers from Ghana. The average annual rainfall is also about $1736 \mathrm{~mm}$ presenting a favourable condition for business and commerce without the interference of the uninvited rainfalls.

\subsection{Study Design}

This paper was explorative in design and used the qualitative explorative method in approach. An explorative design offered the researchers the freedom of delving deeper to understand and explore the emerging themes of diaspora governance. With close to no previous work done on diaspora governance especially for the Ghanaian case in Guangzhou, the approach rendered the best opportunity to appropriately present an accurate assessment and narrative of how the Ghanaian community managed their affairs in Guangzhou. Mimicking an ethnographical study, the study involved the techniques of observations and participation to collect data. For the purposes of accurate observation and systematic participation, the three most notable converging point of Ghanaians in Guangzhou was chosen as the focal point for data gathering. These places were the Ghana Church (Church of Pentecost), the Ghana Community meetings and the Ghana restaurant. This paper documented the daily interactive proceedings of these three areas mentioned through written records and videos records as a proof of the naturalistic ground of the Ghanaian community in a Chinese habitat.

\subsection{Sampling, Population and Data Collection}

Observation and data collection took place in the following manner in an ongoing processes. A total of 46 and 39 church services in 2016 and 2017 respectively were attended with different forms of records taken at the convenience of the respondents. Concurrently 43 and 38 visits were embarked at the Ghana restaurants between March 2016 and January 2017 respectively. There was further collection of demographical data for all the 10 Ghana community meetings within the period of 11 months (from 2016 to 2017). It is however apparent to say that only recorded demographical could be taken because of the inaccessibility of permit for the recording of agenda discussed (due to its sensitivity). These notwithstanding, inferences as well as implied applications were made by this paper from unrecorded observations made in the Ghana community meetings.

Open-ended interviews were organized for 14 officials with 8 of these interviews granted in person while 3 were on phone. Participants included 6 leaders of the Ghana community, 2 leaders from the Ghana restaurant, 4 leaders from the church and 2 officials from the Ghana Embassy in Beijing. 10 respondents were granted interviews for the semi-closed category with 4 of them being members of the Ghana community, 3 of them from the church and 3 of them being customers of the Ghana restaurant. The last groups of interviews were organized under the closed-ended category with a total of 10 respondents. 3 of them were members of the Ghana community, 4 of them from the church membership and 3 being customers of the Ghana restaurant. 
A broad qualitative method of content analysis was then used to analyze the data collected. Content analysis was in the form of logical interpretation of gathered information from both primary and secondary sources and did not include codifying core concepts or phrases in texts for the purpose of empirical analysis.

\section{Findings}

\subsection{Structure of Ghanaian Diaspora Governance in Guangzhou}

The structure of governance approach influences the nature of governance. Diaspora governance within the Ghanaian diaspora in China can classified into two different forms; the formal and informal (Figure 1). The formal approach to diaspora governance regulates the affairs of the Ghanaian diaspora using five different domains. These are:

1) Institutional capacity.

2) Migrant rights.

3) Safe and orderly migration.

4) Labor migration management.

5) Regional and international co-operation and other partnerships.

A critical look at these domains indicates a macro nature of governance. Macro governance broadly dealt with institutions and policy regulation. Institutional capacity as a domain of the formal diaspora governance ultimately aims as ensuing a supportive diasporic life for Ghanaians in the diaspora however; it does not deal directly with the individual members of the Ghanaian diaspora.

This is similar to the other domains of the formal approach to diaspora governance. The study found that the macro diaspora governance structures positioned within the Ghanaian community were weak and ineffective. This is reflected in the performance evaluation of the governance mechanism adopted and their utility in addressing pressing needs of Ghanaians.

\subsection{Performance Evaluation of Guangzhou Governance Approaches to the Ghanaian Diaspora Community}

The results as presentedin the table explain formal indicators for the measurement of diaspora governance in Guangzhou. Generally the study participants presents an unsatisfactory score after measuring it with 5 domains of governance measurement adopted for use in this study. Though, Ghanaians considered the formal governance approach as ineffective, the findings did not suggest that

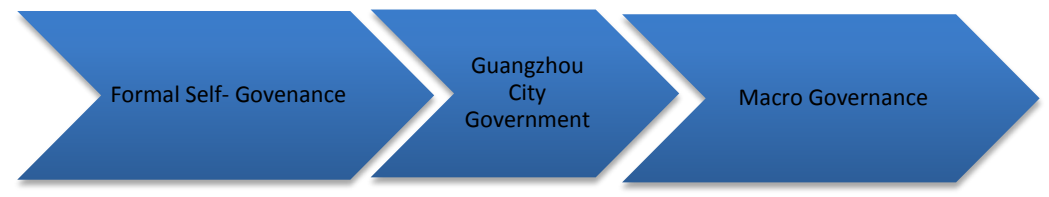

Figure 1. Different forms of governance structures for Ghanaian diaspora community in Guangzhou. 
Guangzhou government was not doing anything about the governance of the Ghanaian diaspora in Guangzhou. China has unique strategies for handling different social challenges though formal diaspora governance was found to be limited justifying the reason why many Ghanaians resort more to the informal diaspora governance systems (Table 1).

\subsection{Dominant Features and Underlying Triggers Accounting for Preference to Informal Diasporan Governance Systems among Ghanaian Community in Guangzhou}

The informal diaspora governance on the other hand takes the form of micro governance. By implication, it deals with the daily as well as the person-to-person governance in the diaspora. In the case of the Ghanaian diaspora under study, the major informal institution is arguably the church. Normally the micro diaspora governance approach does not bother much on the external boundaries of governance but rather the immediate demand of the members of the diaspora.

This paper indicates however that the Ghana church is the fabric supporting the entire informal governance structure of the Ghana diaspora in China. The diagram below shows why the informal government system sustains the Ghanaian community.

The paper therefore proposes a Religio-political diaspora governance theory as an explanation for the existing governance system of the Ghanaians in the Chinese diaspora. The Religio-political diaspora governance theory is therefore explained as the political evolution of the attaining, acceptance and usage of political governing power by a religious entity to govern a community in the diaspora out of their free-will due to the necessity, demand and the acclamation of the religious entity. By explanation, this theory proposes that in a diaspora (where the systems of governance are arguably fragile) the possibility of formal institutions firmly holding-on and leading a said community is much a luxury than a necessity. Hence members of the diaspora most likely would venture out for other governance structures that have reputation and is well organized. This position was reaffirmed by the chairman of the Ghana community in Guangzhou.

"The Ghana Church (i.e. The Church of Pentecost) brings we the Ghanaians here together. I think this is the reason why many of our members listen to them a lot'.

An interview with the leader of the Pentecost Church in Guangzhou reflected the same view.

"Our responsibility to Ghanaians in Guangzhou has been to serve as a spiritual and social foundation for development and progress. We are confident that this responsibility is what makes our brothers and sisters attend to our interventions as and when needed".

A female trader who couples as a member of the Ghana community buttressed the earlier stated views with this comment; 
Table 1. Guangzhou Government's performance on formal diaspora governance.

\begin{tabular}{|c|c|c|}
\hline Domain & Indicators & Remarks \\
\hline Institutional Capacity & $\begin{array}{l}\text { 1) Availability and knowledge about } \\
\text { institutional capacity in Guangzhou for the } \\
\text { Ghanaian diaspora in Guangzhou }\end{array}$ & Unsatisfactory \\
\hline Migrant Rights & $\begin{array}{l}\text { 2) Ghanaians access to social services (e.g. security, } \\
\text { health services, education, rights to work) } \\
\text { 3) Family reunification rights } \\
\text { 4) Residency and Citizenship }\end{array}$ & Unsatisfactory \\
\hline $\begin{array}{l}\text { Safe and Orderly } \\
\text { Migration }\end{array}$ & $\begin{array}{l}\text { 5) Ghanaian's safety and proper migration. } \\
\text { 6) Second is human trafficking and smuggling }\end{array}$ & Unsatisfactory \\
\hline $\begin{array}{l}\text { Migration Labor } \\
\text { Management }\end{array}$ & $\begin{array}{l}\text { 7) Connecting migration to national development } \\
\text { needs }\end{array}$ & Unsatisfactory \\
\hline $\begin{array}{l}\text { Regional and } \\
\text { International } \\
\text { Co-Operation and } \\
\text { Other Partnerships }\end{array}$ & $\begin{array}{l}\text { Guangzhou government readiness to dialogue with } \\
\text { International Partners to handle issues of diaspora }\end{array}$ & Unsatisfactory \\
\hline
\end{tabular}

"As for me I think the church people organize themselves and the Ghana people well so I trust their decisions and their lead".

The central sub themes that's surfaces as a governance challenge confronting the Ghanaian diaspora in China are;

- The presence of a well-solidified and thriving diaspora;

- A sense of religiosity in the diaspora;

- Failure or ineffectiveness of the formal institutions to diaspora governance.

From the diagram in Figure 2, the Ghana Church in Guangzhou micro governs the Ghanaian community in Guangzhou using informal diasporally localized institutions.

\section{Discussions}

This study was a qualitative case study that focused on the diaspora governance issues facing the Ghanaian community in Ghanzhou China. The study reiterated that, the focus of governance is its effectiveness in the ability to serve the governed. Both the formal and the informal governance approaches in the Ghanaian diaspora in Guangzhou confirms this statement. China seeks to be effective and appropriate for the bettering of the lives of the Ghanaian diaspora in Guangzhou. This notwithstanding a comparative analysis shows a firm dual systems of government the formal and the informal approaches of governance with a firm foundation associated with theor the informal approach (Bork-Hüffer et al., 2014).

The findings demonstrate the need to reexamine the contextualized dualistic nature of effectiveness of the different governance arrangements being used by the Ghanaian community in China. First is the ability to implement the decisions of governance and second is how influentially beneficial such governance 

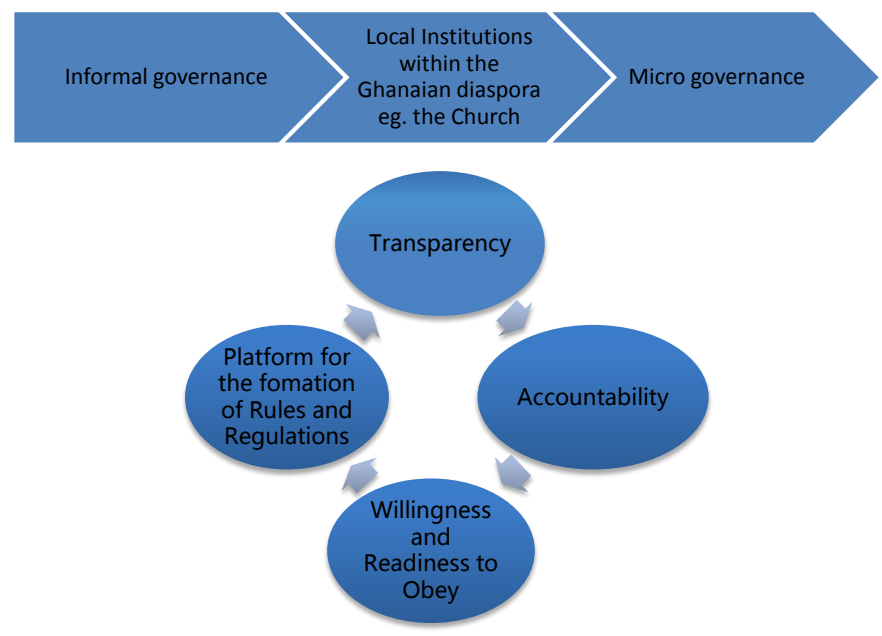

Figure 2. Central themes underpinning informal religio-politico informal governance for diasporan Ghanaians in Guangzhou.

are to the diaspora. The formal approach is often found to be backed by government apparatus and this makes it appear to have a greater tendency to implement decision, laws and regulations with respect to governing the diaspora. In an observation that was made during a time where the government of Guangzhou decided to reduce the number of permanent residents, it was simply done by changing the requirements needed from qualifying for a resident visa. This became a formalized means of implementing the new law of residency (Bork-Hüffer \& Yuan, 2014). Consistent with Bork-Hüffer and Yuan (2014) summation "Along with new provisions facilitating visa application, easing general entry and application for permanent residence, the new law introduces additional measures for stricter supervision of the entry of foreigners and specifies prohibited activities related to the entry and exit of foreigners. The new law also specifies penalties for foreigners committing illegal activities and for persons providing support to these foreigners".

The study understood such laws to be implemented to the core. In many cases, laws are effective with the formal approach to diaspora governance because it is backed by state powers and implemented by state authorities. In 2017 for instance, the leadership of the Ghanaian community decided to mandate membership by a registered card ownership. All Ghanaians in the diaspora both registered and non-registered were demanded to obtain a membership card. However from June 2017 up until February 2018, only 58 Ghanaians had picked up their membership cards. This demonstrates the effect of informal structures in ensuring compliance as compared to the formal arrangements. However, in contrast to the few formal compliant regulations that the Ghanaian community may ascribe to, the study indicates that there is a major difficulty in the effectiveness of the formal laws. This can be explained partly by the consistently changing formal laws in the diaspora. By explanation, the difficulty in the effectiveness of implementation has been caused by the very nature of the implementation. 
The study identified that, the limitation in formal regulation enforcement and its backlash with the diasporan non-compliant indicates and generates the thinking that as though there is not diaspora. A central finding that has weakened the formalized governance system among the Ghanaian community was language. In validating the argument, this paper further emphasizes that language barrier has become a major reason why the domains of the formal governance in the Ghanaian diaspora of Guangzhou has not worked. Corroborating this, the chairman of the Ghana community in an interview indicated that many of the Ghanaian merchants are not accustomed with the Chinese language (both written and spoken) and hence are deterred from visiting Chinese government agencies in times of need.

This is because of the strong influence of the Chinese language in the daily life of Chinese in Guangzhou. For this reason, Ghanaians are more comfortable dealing with themselves in almost all circumstance.

However, suggestions from Bodomo (2010) on the essence of the use of the "calculator language" could contribute to enhancing communication between Africans in the diaspora and the Chinese. As reiterated by Bodomo, the calculator language may not be useful in formalized settings. Thus contrary to the use of the calculator language, it falls short of its relevance for official use. A major finding affecting the formalized governance structure with the Chinese was the associated complexity of the Guangzhou governance structure. There is a clear and firm policy strategy on governing African migrants but this was found to be much more complex then it was thought out to be.

Corroboratory, the China government approach has been post event intervention or "problem interventions". This is corroborated by Elochukwu (2016) who suggest that; "Until recently migration was treated like a footnote in the Africa-China discourse. Previously researchers and the media had focused attention on the "cost-benefit analysis" of China's economic penetration of the African continent". It is this seeming neglect of the domain of diaspora governance that has caused very little to be known and documented to stir discourse and innovative idea to think about. Several research works have been conducted in the area of trade and businesss yet little or lose to none within the confines of diaspora governance structure evaluation.

The excessive emphasis on trade, commerce and business gets derailed if the governance structures are weak. This can be partly accredited to the huge emphasis placed on business and commerce in relations to the migrants in Guangzhou. Meanwhile other studies have indicated that the intent of African migrants in China might not only be for the reason of commerce. The need to use groups as agents and representative has been advocated for by Bodomo (2015a) (on the African-China research), who submits that there are four leading groups of authors in terms of number and quality of journal on the subject of African communities in China.

In all, very limited number of studies have been conducted on diaspora go- 
vernance. Included in the few studies are Li Zhigang et al. working mainly on health issues. Other works include Bertoncello and Bredeloup (2007), Bredeloup (2012), Le Bail (2009), Müller and Wehrhahn (2013), and Lan (2014).

According to Li (2015) despite the previous works on diaspora governance by previous scholars, the application of the concept of Bodomo's "immigrant community as bridge" was missing. Corroborating the concept, the present study identified the church as being the immediate home for all foreigners. This clearly shows that Africans (Ghanaians) may be visiting visit Guangzhou for other purposes and not entirely for trade. This reason for visiting Guangzhou-China, though very important has not received major attention and policy redirection by the authorities that be and hence has cause a major uncertainty for the main stakeholders in the relationship herein discussed.

These observed weaknesses in the formal structures have given rise to the acceptance of the informal governance arrangements facilitated by the church as a considered effective and efficient platform for managing the affairs of the Ghanaian community. Reiterating this, the chairman of the Ghana community indicated that there is a general positivity with trust for the structures and the leadership of the Ghana community leadership. It stems from the strong bond between Africans in Guangzhou-China in general. However, some scholars have argued that Bodomo, 2014 these trust arrangements are continually being shaped and remain in the process of development and may not be static (Bodomo \& Ma, 2012; Li et al., 2007). Accordingly, there are socio-culturally contentious processes that are intersected by observable and non-observable factors (Bodomo, 2009). These intersections have created room for cooperation that transcends race, class, and migrant status. In a specific role, and consistent with earlier submission by religious institutions of the Ghanaian diaspora in Guangzhou China, continue to present a safe haven for Ghanaian migrants in Guangzhou (Bodomo, 2015b; Li, Dray-Novey, \& Kong, 2007; Lyons, Brown, \& Li, 2009). The church environment both presents an avenue for cultural retouch and religious fulfilment.

\section{Conclusion}

This study focused on investigating how diasporas self-govern to explore the governance of the African diaspora in Guangzhou. Data collection and analyses were done through interviews, and focus group discussions and observations to shed light on the different complexly interwoven arrangements between the formal and informal structures that govern the Ghanaian diaspora in Guangzhou. This study established that there are formal and informal structures for governance in the diaspora.

The formal structure takes the form of the constitutional document of the Ghanaian diaspora and the major informal institution is the church of Pentecost (much known as the Ghana Church). It was revealed in the study that the constitutional structures that are needed for the proper functioning of the formal 
institution for governance are very weak and have caused two effects. The first effect is that there seems to be lost in confidence in the formal structure of self-governance in the diaspora. The second effect is that this has given rise to the high confidence placed in the informal institution of self-governance.

The major limitation of this study was the difficulty involved in accessing information from the Chinese government officials. Secondly majority of the limited secondary data on this study from Chinese scholars were written in the Chinese language, which needs very technical and professional to know how to interpret. Lastly the sensitivity of the topic of "religion and faith" in China restricted the African respondents to be selective in the delivery of information.

\section{Author' Contributions}

PLA conceived and designed, conducted the interviews, analysed the data and wrote the manuscripts. SCYA revised the manuscripts. All authors agreed to the publication.

\section{Funding}

This study did not have any funding. It suffices to say therefore that the study was holistically self-funded by the researchers.

\section{Acknowledgements}

We are grateful to the supervisory support of Professor Zhonghua Guo of Sun Yat-sen University and also the analytical role played by Ohene Opoku Agyemang of the Jinan University both in Guangzhou China. Secondly we want acknowledge the Guangzhou Church of Pentecost (The Ghana Church) for opening their doors for our research and last to the leadership of the Ghana Community Executive and members.

\section{Conflicts of Interest}

The authors declare no conflict of interest.

\section{References}

Bertoncello, B., \& Bredeloup, S. (2007). The Emergence of New African 'Trading Posts' in Hong Kong and Guangzhou. China Perspectives, 1, 94-105.

Bodomo, A. (2009). The African Presence in Contemporary China. The China Monitor, No. 36, 4-6.

Bodomo, A. (2010). The African Trading Community in Guangzhou: An Emerging Bridge for Africa-China Relations. The China Quarterly, 203, 693-707. https://doi.org/10.1017/S0305741010000664

Bodomo, A. (2012). Africans in China: A Sociocultural Study and Its Implications on Africa China Relations. Amherst, New York: Cambria Press.

Bodomo, A. (2014). Africans in China: The Experiences from Education and Training. The International Conference of China and Africa Media, Communications and Public Diplomacy, Beijing, 10-11 September 2014. https://www.cmi.no/file/2911.pdf 
Bodomo, A. (2015a). Africans in China: Guangzhou and beyond-Issues and Reviews. The Journal of Pan African Studies, 7, 1-9.

Bodomo, A. (2015b). The African Traveller and the Chinese Customs Official: Ethnic Minority Profiling at Border Check Points in Hong Kong and China? Journal of African American Studies, 19, 52-64. https://doi.org/10.1007/s12111-014-9289-2

Bodomo, A., \& Ma, E. (2012). We Are What We Eat: Food in the Process of Community Formation and Identity Shaping among African Traders in Guangzhou and Yiwu. African Diaspora, 5, 3-26. https://doi.org/10.1163/187254612X646198

Bodomo, A., \& Ma, G. (2010). From Guangzhou to Yiwu: Emerging Facets of the African Diaspora in China. International Journal of African Renaissance Studies-Multi-, Inter- and Transdisciplinarity, 5, 283-289. https://doi.org/10.1080/18186874.2010.534854

Bork-Hüffer, T., \& Yuan, Y.-I. (201 4). The Management of Foreigners in China: Changes to the Migration Law and Regulations during the Late Hu-Wen and Early Xi-Li Eras and Their Potential Effects. International Journal of China Studies, 5, 571-597.

Bork-Hüffer, T., Rafflenbeul, B., Kraas, F., \& Li, Z. (2014). Global Change, National Development Goals, Urbanisation and International Migration in China: African Migrants in Guangzhou and Foshan. In F. Kraas, S. Aggarwal, M. Coy, \& G. Mertins (Eds.), Megacities: Our Global Urban Future (pp. 135-150). Dordrecht: Springer. https://doi.org/10.1007/978-90-481-3417-5_10

Bredeloup, S. (2012). African Trading Post in Guangzhou: Emergent or Recurrent Commercial form? African Diaspora, 5, 27-50. https://doi.org/10.1163/187254612X646206

Cai, G., \& Yu, H. (2008). African Merchants and their Activities in Guangzhou: The Case of China-Africa Trading Post in Dengfeng Community. Guangzhou: Guangzhou Academy of Social Sciences.

Elochukwu, A. (2016) Guangzhou's African Migrants: Implications for China's Social Stability and China-Africa Relations. Contemporary Chinese Political Economy and Strategic Relations: An International Journal, 2, 1195-1213.

Lan, S. S. (2014). Between Mobility and Immobility: Undocumented African Migrants Living in the Shadow of the Chinese STATE. In D. G. Wang, \& S. J. He (Eds), Mobility, Sociability and Wellbeing of Urban Living (pp. 3-21). Berlin, Heidelberg: Springer-Verlag.

Le Bail, H. (2009). Foreign migration to China's City-Markets: The Case of African Merchants. Asie Visions 19. Institut Français des Relations Internationales (Ifri). https://www.ifri.org/sites/default/fil es/atoms/files/av19lebailgb.pdf

Li, A. (2015). African Diaspora in China: Reality, Research and Reflection. Journal of Pan African Studies, 7, 10-43.

Li, L., Dray-Novey, A. J., \& Kong, H. (2007). Beijing: From Imperial Capital to Olympic City. New York: Palgrave Macmillan.

Li, Z., \& Du, F. (2012). Production of China's New Social Space in the City under "Transnational Entrepreneurialism": A Case Study on African Economic Zone in Guangzhou. Urban Space Studies, 36, 25-31.

Lyons, M., Brown, A, \& Li, Z. (2009). In the Dragon's Den: African Traders in Guangzhou 2005-2008. IDEAR Working Paper.

Müller, A., \& Wehrhahn, R. (2013). Transnational Business Networks of African Intermediaries in China: Practices of Networking and the Role of Experiential Knowledge. Die Erde: Zeitschrift der Gesellschaft für Erdkunde zu Berlin, 144, 82-97.

$\mathrm{Xu}, \mathrm{T}$. (2010). The Social Adaptation of African Merchants in Guangzhou, China. Ph.D. Dissertation. Guangzhou: Sun Yat-sen University. 